\title{
Studies on Flavins
}

\section{The Preparation of Heavy Atom Derivatives}

\author{
LA J OS MARON \\ Institute of Inorganic and Physical Chemistry, University of Stockholm, \\ S.104 05 Stockholm 50, Sweden
}

\begin{abstract}
The preparation of the following bromine substituted compounds, required for our X-ray crystallographic investigations, are described: 4-amino-3-bromo-5-nitro-o-xylene, 3-bromo-4-methylamino-5-nitro-oxylene, 4,5-diamino-3-bromo-o-xylene, 5-amino-3-bromo-4-methylamino-o-xylene, 9-bromo-7,8-dimethylalloxazine, 9-bromo-3,7,8-trimethylalloxazine, 9-bromo-7,8,10-trimethylisoalloxazine, 9-bromo-3,7, 8,10-tetramethylisoalloxazine, 9-bromo-1,3,7,8-tetramethylalloxazine, 5-acetyl-9-bromo-5,10-dihydro-7,8-dimethylalloxazine, 5-acetyl-9bromo-5,10-dihydro-3,7,8-trimethylalloxazine, 5-acetyl-9-bromo-5,10dihydro-7,8,10-trimethylalloxazine, 5-acetyl-9-bromo-5,10-dihydro-3, 7,8,10-tetramethylalloxazine, 5-acetyl-9-bromo-5,10-dihydro-1,3,7,8tetramethylalloxazine, $\quad 5$-acetyl-9-bromo-5,10-dihydro-1,3,7,8,10pentamethylalloxazine, 9-bromo-5,10-dihydro-1,3,7,8,10-pentamethylalloxazine and riboflavine silver-chelate perchlorate.
\end{abstract}

$\mathrm{T}$ he vital role of the flavo-proteins in biological redox processes has inspired extensive research on the chemistry of the constituent molecules of this group of enzymes. The research in this field has been reviewed in several recent articles..$^{1-5}$

The preparation of heavy atom derivatives of flavins is a part of our research project concerning structural studies of flavin compounds in different states of oxidation. The numbering of the atoms forming the alloxazine ring system of the flavins is shown in Fig. 1.

The bromination of 4-amino-5-nitro-o-xylene and 4-methylamino-5-nitro-oxylene, respectively, in glacial acetic acid-sodium acetate solution afforded I and II. The reduction of I and II with stannous chloride in concentrated hydro-

Fig. 1. The numbering of atoms adopted for the alloxazine molecule.<smiles></smiles>

Acta Chem. Scand. 26 (1972) No. 3 
chloric acid gave 4,5-diamino-3-bromo-o-xylene (III) and 5-amino-3-bromo-4methylamino-o-xylene (IV).

To yield 9-bromo-7,8-dimethylalloxazine (V), 9-bromo-3,7,8-trimethylalloxazine (VI), 9-bromo-7,8,10-trimethylisoalloxazine (VII) and 9-bromo-3,7, 8,10 -tetramethylisoalloxazine (VIII), III and IV were condensed with alloxan ${ }^{6}$ and 3-methylalloxan, ${ }^{7}$ respectively.

The methylation of $\mathrm{V}$ with dimethyl sulphate in dimethylformamide solution ${ }^{8}$ gave 9 -bromo-1,3,7,8-tetramethylalloxazine (IX).

The reductive acetylation of V, VI, VII, VIII, and IX in acetic acid-acetic anhydride solution with zinc powder ${ }^{8}$ afforded 5-acetyl-9-bromo-5, 10-dihydro7,8-dimethylalloxazine $(\mathrm{X}), \quad 5$-acetyl-9-bromo-5,10-dihydro-3,7,8-trimethylalloxazine (XI), 5-acetyl-9-bromo-7,8,10-trimethylalloxazine (XII), 5-acetyl9-bromo-5,10-dihydro-3,7,8,10-tetramethylalloxazine (XIII) and 5-acetyl-9bromo-5,10-dihydro-1,3,7,8-tetramethylalloxazine (XIV).

The methylation of XIV with dimethyl sulphate in dimethylformamide solution ${ }^{8}$ gave 5-acetyl-9-bromo-5,10-dihydro-1,3,7,8,10-pentamethylalloxazine (XV).

The mild acid hydrolysis ${ }^{8}$ of XV afforded 9-bromo-5,10-dihydro-1,3,7,8,10pentamethylalloxazine (XVI).

To yield riboflavine silver-chelate perchlorate (XVII), riboflavine perchlorate was treated with silver nitrate in slightly acidic acetone solution. The crystal and molecular structure of VIII, ${ }^{9} \mathrm{XIV},{ }^{10} \mathrm{XV},{ }^{11}$ and $\mathrm{XVI}{ }^{12}$ has been determined by $\mathrm{X}$-ray diffraction methods.

\section{EXPERIMENTAL}

All melting points are uncorrected. Evaporations were carried out under reduced pressure at a bath temperature below $40^{\circ}$.

Chromatography. Paper: Whatman No. 1. Thin layer chromatography. Absorbent: Kieselgel G nach Stahl, Merck. Solvent: butanol-formic acid-water 77:10:13. The spots on the chromatograms were located with UV-light.

4-Amino-3-bromo-5-nitro-o-xylene (I). 4-Amino-5-nitro-o-xylene $(16.6 \mathrm{~g})$ and sodium acetate $(8.5 \mathrm{~g})$ were dissolved in acetic acid $(100 \mathrm{ml})$. Bromine $(16 \mathrm{~g})$ dissolved in acetic acid $(50 \mathrm{ml})$ was added with stirring during $2 \mathrm{~h}$ at room temperature. A few crystals of iodine were used as catalyst. The stirring was continued for $3 \mathrm{~h}$, the acetic acid evaporated in vacuo and the residue treated with water. Recrystallization from acetic acid gave crystals $\left(18.0\right.$ g), m.p. $128-130^{\circ}$. (Found: C 39.1; $\mathrm{H} 3.73 ; \mathrm{N}$ 11.3. Calc. for $\mathrm{C}_{8} \mathrm{H}_{9} \mathrm{BrN}_{2} \mathrm{O}_{2}$ : C 39.2; H 3.73; N 11.4.)

3-Bromo-4-methylamino-5-nitro-o-xylene (II). 4-Methylamino-5-nitro-o-xylene (18.0 g) sodium acetate $(8.5 \mathrm{~g})$ and a few crystals of iodine were dissolved in acetic acid $(100 \mathrm{ml})$ and treated with bromine $(16 \mathrm{~g})$ dissolved in acetic acid $(50 \mathrm{ml})$ with stirring for $2 \mathrm{~h}$ at room temperature. The stirring was continued for $3 \mathrm{~h}$, the acetic acid evaporated in vacuo and the residue treated with water. Recrystallization from ethanol gave crystals $(19 \mathrm{~g})$,

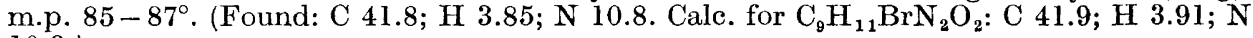
10.9.)

4,5-Diamino-3-bromo-o-xylenedihydrochloride (III). 4-Amino-3-bromo-5-nitro-o-xylene $(24 \mathrm{~g})$ was dissolved in $37 \%$ hydrochloric acid $(250 \mathrm{ml})$ and treated with $\mathrm{SnCl}_{2} \cdot 2 \mathrm{H}_{2} \mathrm{O}$ $(110 \mathrm{~g})$ with stirring. The solution was heated to boiling for $15 \mathrm{~min}$ and cooled to room temperature. The mixture was neutralized with sodium hydroxide $(300 \mathrm{~g})$ dissolved in water $(400 \mathrm{ml})$ and extracted with ethyl ether; the ether extract was dried with sodium sulphate and filtrated. The diamine was precipitated with hydrogen chloride as the dihydrochloride. Recrystallization from ethanol-water 1:1 containing some hydrochloric acid gave crystals $(21 \mathrm{~g})$, m.p. $125-127^{\circ}$. (Found: $\mathrm{C} 33.3 ; \mathrm{H} 4.05 ; \mathrm{N}$ 9.7. Calc. for $\mathrm{C}_{8} \mathrm{H}_{13} \mathrm{BrCl}_{2} \mathrm{~N}_{2}$ : $\mathrm{C} 33.4 ; \mathrm{H} 4.20 ; \mathrm{N}$ 9.7.) 
5-Amino-3-bromo-4-methylamino-o-xylene dihydrochloride (IV). 3-Bromo-4-methylamino-5-nitro-o-xylene $(25.8 \mathrm{~g})$ was dissolved in $37 \%$ hydrochloric acid $(250 \mathrm{ml})$ and treated with $\mathrm{SnCl}_{2} .2 \mathrm{H}_{2} \mathrm{O}(110 \mathrm{~g})$ with stirring. The solution was heated to boiling for 15 min and cooled to room temperature. The mixture was neutralized with sodium hydroxide $(300 \mathrm{~g})$ dissolved in water $(400 \mathrm{ml})$ and extracted with ethyl ether. The ether extract was dried with sodium sulphate and filtered. The diamine was precipitated with hydrogen chloride as the dihydrochloride. Recrystallization from ethanol-water containing some hydrochloric acid gave crystals $(30 \mathrm{~g})$, m.p. $120-122^{\circ}$. (Found: $\mathrm{C} 35.8 ; \mathrm{H} 4.70 ; \mathrm{N}$ 9.3. Calc. for $\mathrm{C}_{9} \mathrm{H}_{15} \mathrm{BrCl}_{2} \mathrm{~N}_{2}$ : C 35.9; $\mathrm{H} \mathrm{4.69;} \mathrm{N} 9.3$.)

9-Bromo-7,8-dimethylalloxazine (V). 4,5-Diamino-3-bromo-o-xylene dihydrochloride $(5.8 \mathrm{~g})$ was dissolved in acetic acid $(150 \mathrm{ml})$ containing sodium acetate $(3.3 \mathrm{~g})$ with stirring at $70^{\circ}$. Alloxan monohydrate $(4.8 \mathrm{~g})$ and boric acid $(1.9 \mathrm{~g})$ were dissolved in acetic acid $(50 \mathrm{ml})$ at $70^{\circ}$. The two solutions were brought together and stirred overnight. The precipitated alloxazine was filtered off and washed with water and acetic acid. Recrystallization from acetic acid gave crystals $\left(8 \mathrm{~g}\right.$ ), m.p. $325-327^{\circ}$. (Found: C 44.8;

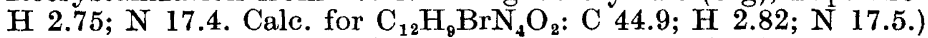

9-Bromo-3,7,8-trimethylalloxazine (VI). 4,5-Diamino-3-bromo-o-xylene dihydrochloride $(5.8 \mathrm{~g})$ was dissolved in acetic acid $(150 \mathrm{ml})$ containing sodium acetate $(3.3 \mathrm{~g})$ with stirring at $70^{\circ}$. 3-Methyl-alloxan monohydrate $(5 \mathrm{~g})$ and boric acid $(1.9 \mathrm{~g})$ were dissolved in acetic acid $(50 \mathrm{ml})$ at $70^{\circ}$. The two solutions were brought together and stirred overnight. The precipitated alloxazine was filtered off and washed with water and acetic acid. Recrystallization from acetic acid gave crystals $(8.2 \mathrm{~g})$, m.p. $335-340^{\circ}$. (Found: C 46.5; $\mathrm{H}$ 3.25; $\mathrm{N}$ 16.7. Calc. for $\mathrm{C}_{13} \mathrm{H}_{11} \mathrm{BrN}_{4} \mathrm{O}_{2}$ : $\mathrm{C} 46.6 ; \mathrm{H} \mathrm{3.31;} \mathrm{N} 16.6$.)

9-Bromo-7,8,10-trimethylisoalloxazine (VII). 5-Amino-3-bromo-4-methylamino-oxylene dihydrochloride $(4.1 \mathrm{~g})$ was dissolved in water $(100 \mathrm{ml})$ with stirring at $90^{\circ}$ and alloxan monohydrate $(3 \mathrm{~g})$ was added in one portion. The stirring was continued for $20 \mathrm{~min}$ and the precipitated alloxazine was filtered off, washed with water and dried. Recrystallization from acetic acid-water $2: 1$ gave crystals $(3.6 \mathrm{~g})$, m.p. $270-272^{\circ}$. (Found: C 46.6; $\mathrm{H} 3.23 ; \mathrm{N} \mathrm{16.7.} \mathrm{Calc.} \mathrm{for} \mathrm{C}_{13} \mathrm{H}_{11} \mathrm{BrN}_{4} \mathrm{O}_{2}$ : C 46.6; $\mathrm{H} \mathrm{3.31;} \mathrm{N} \mathrm{16.7.)}$

9-Bromo-3,7,8,10-tetramethylisoalloxazine (VIII). 5-Amino-3-bromo-4-methylamino$o$-xylene dihydrochloride $(4 \mathrm{~g})$ was dissolved in water $(100 \mathrm{ml})$ with stirring at $90^{\circ}$ and 3 -methylalloxan monohydrate $(3.5 \mathrm{~g})$ was added in one portion. The stirring was continued for $20 \mathrm{~min}$ and the precipitated alloxazine was filtered off, washed with water and dried. Recrystallization from acetic acid-water $2: 1$ gave crystals $(3.5 \mathrm{~g}), \mathrm{m} . \mathrm{p} .246-248^{\circ}$. (Found: C 48.3; $\mathrm{H} \mathrm{3.61;} \mathrm{N} \mathrm{16.0.} \mathrm{Calc.} \mathrm{for} \mathrm{C}_{14} \mathrm{H}_{13} \mathrm{BrN}_{4} \mathrm{O}_{2}: \mathrm{C} 48.2 ; \mathrm{H} 3.75 ; \mathrm{N}$ 16.0.)

9-Bromo-1,3,7,8-tetramethylalloxazine (IX). 9-Bromo-7,8-dimethylalloxazine $(3.2 \mathrm{~g})$ and potassium carbonate $(4 \mathrm{~g})$ in dimethylformamide $(35 \mathrm{ml})$ were heated to $90^{\circ}$ with stirring. Into the reaction mixture dimethyl sulphate-dimethylformamide $1: 1 \quad(9.5 \mathrm{ml})$ was added dropwise during $1 \mathrm{~h}$. The stirring was continued for $\mathrm{l} \mathrm{h}$ and potassium carbonate $(2.4 \mathrm{~g})$ was added again. After $3 \mathrm{~h}$ of stirring the dimethylformamide was evaporated in vacuo and the residue washed with $2 \mathrm{M}$ ammonium hydroxide and water. Recrystallization from the acetic acid gave crystals $(3 \mathrm{~g})$, m.p. $240-245^{\circ}$. (Found: $\mathrm{C} 48.0 ; \mathrm{H} 3.70 ; \mathrm{N} 16.0$. Calc. for $\mathrm{C}_{14} \mathrm{H}_{13} \mathrm{BrN}_{4} \mathrm{O}_{2}$ : C $48.1 ; \mathrm{H} 3.75 ; \mathrm{N}$ 16.0.)

5-Acetyl-9-bromo-5,10-dihydro-7,8-dimethylalloxazine $(X)$. 9-Bromo-7,8-dimethylalloxazine $(4 \mathrm{~g})$ was dissolved in acetic acid-acetic anhydride $1: 1(80 \mathrm{ml})$ and heated to boiling with stirring. Zinc powder $(4 \mathrm{~g})$ was added during $1 \mathrm{~h}$. The refluxing was continued for $30 \mathrm{~min}$, the mixture filtered hot and evaporated in vacuo. The residue was washed with water, dissolved in 1 M sodium hydroxide and precipitated with acetic acid. Recrystallization from acetic acid gave crystals $\left(2.5 \mathrm{~g}\right.$ ), m.p. $280-282^{\circ}$. (Found: C 46.0; $\mathrm{H}$ 3.51; $\mathrm{N}$ 15.2. Calc. for $\mathrm{C}_{14} \mathrm{H}_{13} \mathrm{BrN}_{4} \mathrm{O}_{3}: \mathrm{C} 46.0 ; \mathrm{H} \mathrm{3.59;} \mathrm{N}$ 15.3.)

5-Acetyl-9-bromo-5,10-dihydro-3,7,8-trimethylalloxazine (XI).9-Bromo-3,7,8-trimethylalloxazine $(5 \mathrm{~g})$ was dissolved in acetic acid-acetic anhydride $1: 1(100 \mathrm{ml})$ and heated to boiling with stirring. Zinc powder $(5 \mathrm{~g})$ was added during $1 \mathrm{~h}$. The refluxing was continued for $30 \mathrm{~min}$, the mixture filtered hot and evaporated in vacuo. The residue was washed with water, then dissolved in $1 \mathrm{M}$ sodium hydroxide and precipitated with acetic acid. Recrystallization from acetic acid gave crystals $(3 \mathrm{~g})$, m.p. 290-295 ${ }^{\circ}$ (Found: C 47.4; $\mathrm{H} 4.02 ; \mathrm{N} 14.7$. Calc. for $\mathrm{C}_{15} \mathrm{H}_{15} \mathrm{BrN}_{4} \mathrm{O}_{3}$ : $\mathrm{C} 47.5 ; \mathrm{H} 3.99 ; \mathrm{N} 14.8$.)

5-Acetyl-9-bromo-5,10-dihydro-7,8,10-tetramethylalloxazine (XII). 9-Bromo-7,8,10-trimethylisoalloxazine $(4 \mathrm{~g})$ was dissolved in acetic acid-acetic anhydride $1: 1(80 \mathrm{ml})$ and heated to boiling with stirring. Zinc powder $(4 \mathrm{~g})$ was added during $1 \mathrm{~h}$. The refluxing

Acta Chem. Scand. 26 (1972) No. 3 
was continued for $30 \mathrm{~min}$, the mixture filtered hot and evaporated in vacuo. The residue was washed with water, then dissolved in $1 \mathrm{M}$ sodium hydroxide and precipitated with acetic acid. Recrystallization from acetic acid gave crystals $(2.5 \mathrm{~g}), \mathrm{m} . \mathrm{p} .350^{\circ}$. (Found: C 47.3; $\mathrm{H} \mathrm{3.90;} \mathrm{N}$ 14.7. Calc. for $\mathrm{C}_{15} \mathrm{H}_{15} \mathrm{BrN}_{4} \mathrm{O}_{3}: \mathrm{C} 47.5 ; \mathrm{H} 3.99 ; \mathrm{N} 14.8$.)

5-Acetyl-9-bromo-5,10-dihydro-3,7,8,10-tetramethylalloxazine (XIII). 9-Bromo-3,7,8, 10-tetramethylisoalloxazine $(2 \mathrm{~g})$ was dissolved in acetic acid-acetic anhydride $1: 1(40 \mathrm{ml})$ and heated to boiling with stirring. Zinc powder $(2 \mathrm{~g})$ was added during $1 \mathrm{~h}$. The refluxing was continued for $30 \mathrm{~min}$, the mixture filtered hot and evaporated in vacuo. The residue was washed with water, then dissolved in $1 \mathrm{M}$ sodium hydroxide and precipitated with

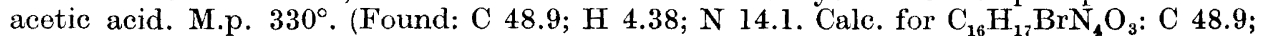
$\mathrm{H}$ 4.36; $\mathrm{N}$ 14.2.)

5-Acetyl-9-bromo-5,10-dihydro-1,3,7,8-tetramethylalloxazine (XIV). 9-Bromo-1,3,7,8tetramethylalloxazine $(2 \mathrm{~g})$ was dissolved in acetic acid-acetic anhydride $1: 1(40 \mathrm{ml})$ and heated to boiling with stirring. Zinc powder $(2 \mathrm{~g})$ was added during $1 \mathrm{~h}$. The refluxing was continued for $30 \mathrm{~min}$, the mixture filtered hot and evaporated in vacuo. The residue was washed with water, then dissolved in $1 \mathrm{M}$ sodium hydroxide and precipitated with acetic acid. Recrystallization from acetone gave crystals $(1 \mathrm{~g}), \mathrm{m} . \mathrm{p} .228-230^{\circ}$. (Found: C $49.0 ; \mathrm{H} \mathrm{4.46;} \mathrm{N}$ 14.1. Calc. for $\mathrm{C}_{18} \mathrm{H}_{17} \mathrm{BrN}_{4} \mathrm{O}_{3}: \mathrm{C} 48.9 ; \mathrm{H} 4.36 ; \mathrm{N} 14.2$.)

5-Acetyl-9-bromo-5,10-dihydro-1,3,7,8,10-pentamethylalloxazine (XV). 5-Acetyl-9. bromo-5,10-dihydro-1,3,7,8-tetramethylalloxazine $(2 \mathrm{~g})$ and potassium carbonate $(4 \mathrm{~g})$ in dimethylformamide $(30 \mathrm{ml})$ were heated to $60^{\circ} \mathrm{C}$ with stirring. Dimethylsulphatedimethylformamide $1: 1(4.7 \mathrm{ml})$ was added dropwise to the reaction mixture during $1 \mathrm{~h}$ and the stirring was continued for $3 \mathrm{~h}$. The dimethylformamide was evaporated in vacuo and the residue was treated with water, the $\mathrm{pH}$ adjusted to 5 with acetic acid and the precipitate filtered. Recrystallization from ethanol gave crystals $(0.7 \mathrm{~g}), \mathrm{m} . \mathrm{p} .235-236^{\circ} \mathrm{C}$. (Found: $\mathrm{C} 50.2 ; \mathrm{H} 4.95 ; \mathrm{N}$ 13.8. Calc. for $\mathrm{C}_{17} \mathrm{H}_{19} \mathrm{BrN}_{4} \mathrm{O}_{3}$ : $\mathrm{C} 50.1 ; \mathrm{H} \mathrm{4.70;} \mathrm{N} 13.8$. )

9-Bromo-5,10-dihydro-1,3,7,8,10-pentamethylalloxazine (XVI). 5-Acetyl-9-bromo-5, 10-dihydro-1,3,7,8,10-pentamethylalloxazine ( $1 \mathrm{~g})$ was heated in ethanol-2 M hydrochloric acid $1: 1(40 \mathrm{ml})$ to $80^{\circ} \mathrm{C}$ for $2 \mathrm{~h}$. The precipitate was filtered off and dried. Recrystallization from ethanol gave crystals $\left(0.4 \mathrm{~g}\right.$ ), m.p. $238-240^{\circ} \mathrm{C}$. (Found: $\mathrm{C} 49.5 ; \mathrm{H} \mathrm{4.41;} \mathrm{N} \mathrm{15.3.} \mathrm{Calc.}$ for $\mathrm{C}_{15} \mathrm{H}_{17} \mathrm{BrN}_{4} \mathrm{O}_{2}: \mathrm{C} 49.3 ; \mathrm{H} \mathrm{4.69;} \mathrm{N} 15.3$.)

Riboflavine silver-chelate perchlorate (XVII). Riboflavine $(0.3764 \mathrm{~g})$ was dissolved in acetone $(20 \mathrm{ml})$ containing perchloric acid $(0.2100 \mathrm{~g})$ at $40^{\circ} \mathrm{C}$. Silver nitrate $(0.1699 \mathrm{~g})$ was dissolved in acetone $(30 \mathrm{ml})$ at $40^{\circ} \mathrm{C}$. The two solutions were brought together and slowly crystallized to give crystals $(0.600 \mathrm{~g})$, m.p. $285-290^{\circ} \mathrm{C}$ with decomposition.

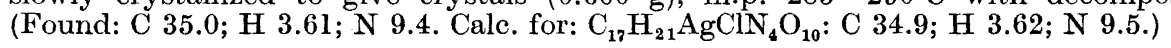

Acknowledgements. The present work has received financial support from the TriCentennial Fund of the Bank of Sweden and from the Swedish Natural Science Research Council. The author is indebted to Professor Peder Kierkegaard for his active interest throughout this work.

\section{REFERENCES}

1. Slater, E. C., Ed., Flavins and Flavoproteins, B. B. A. Library, 8, Elsevier, Amsterdam 1966.

2. Penzer, G. R. and Radda, G. K. Quart. Rev. Chem. Soc. 21 (1967) 43.

3. Hemmerich, P., Veeger, C. and Wood, H. C. S. Angew. Chem. 77 (1965) 1.

4. Ehrenberg, A. Svensk Kem. Tidskr. 74 (1962) 103.

5. Hemmerich, P., Müller, F. and Ehrenberg, A. Oxidases and Related Redox Systems, Wiley, New York 1964, Vol. 1, p. 157.

6. Kuhn, R. and Reinemund, K. Ber. 67 (1934) 1932.

7. Kuhn, R. and Weygand, F. Ber. 68 (1935) 1282.

8. Hemmerich, P., Prijs, B. and Erlenmayer, H. Helv. Chim. Acta 53 (1960) 388.

9. von Glenn, M., Kierkegaard, P. and Norrestam, R. Acta Chem. Scand. 24 (1970) 1490.

10. Werner, P.-E. and Rönnquist, O. Acta Chem. Scand. 24 (1970) 997.

11. Leijonmarck, M. and Werner, P.-E. Acta Chem. Scand. 25 (1971) 2273.

12. Norrestam, R., von Glehn, M., Hagman, L.-O. and Kierkegaard, P. Acta Chem. Scand. 23 (1969) 2199.

Received June 3, 1971. 